(p. 255) given in M. Bouillaud's treatise published in 1835, may indeed be found in Dr. Hope's essay on the disease of the valves, in the London Cyclopedia (1834), as well as in his treatise on diseases of the heart (1832). But it is of a date anterior to these publications, for I have discovered it in Bertin's "Traité des malarlies du cœur et des gros vaisseaux, redigé par J. Bouillaud." Paris, 1824. Thus this favorite piece of medical rhetoric appears, afier all, to be of French origin, and the remark which was applied to M. Bouillaud belongs more justly to Dr. Hope, who should, I think, have given credit for language so liberally borrowed from another.

Boston, Dec. 1836.

Yours truly,

O. W. Holmes.

\title{
EFFECTS OF INTESTINAL IRRITATION ON THE SURFACE OF THE BODY.
}

BY DR. CUN.NINGAH, OF LAKE PORT, IN THE STATF OF ARKANSAS.

IN 1810 , I was called to see a young girl aged 16 , who had been laboring under ulceration of the lower extremities for the last year, and which had resisted every treatment which had been tried to effect a cure.

I found my patient inuch reduced in flesh-of a sallow complexionpulse regular but weak-tongue clean-appetite good-bowels regular, complaining, in fact, of nothing but the state of the lower extremities. These were truly loathsome. On the right limb, from the hip to the ankle, were seventy-five ulcers of various sizes, from a small pea to that of a ten-cent piece. On the left limb were fifiy-five ulcers of a similar nature to those on the right. These ulcers discharged white glairy matter, more resembling the white of an egg, moderately cooked, than anything else with which I could compare it. They had made their appearance about a year before the time I was called in, at fist as small pimples containing a limpid tluid-the vesicles after a wbile broke, and were attended with considerable heat and itching; the sores kept slowly increasing in size, and at the time of my visit some of them were at least a quarter of an inch in depth.

Several physicians who had had the patient under treatment attributed the disease to venereal virus, and had salivated her to a great extent. The mother of the girl said that affer each salivation the sores became worse.

Suspecting intestinal irritation to be the principal, if not the sole cause of the disease, I inquired if worms had, at any time previous to the ulceration, been discharged; when the mother observed that several feet of a tape worm had been passed, soon after which the eruption made its appearance.

Upon this information I founded my plan of cure. Ten papers were prepared and numbered; number 1 contained one grain of tobacco and half a drachm of anise seed; number 10 contained ten grains of tobacco, with a corresponding increase of the anise seed-so that each paper contained an additional grain of tobacco. 
My patient was to eat no supper-boiling water was to be poured on a paper of the medicine at night, and to stand covered over until morning-then to be strained, and the infusion to be taken early every morning, eating nothing for two hours after.

The first four doses excited but little nausea. The eighth produced distressing nausea. After it had subsided, I gave a large dose of castor oil, which brought a tape worm ten yards in length. Within two days after the expulsion of the worm, the ulcers assumed a healing aspect, and in three weeks I had the satisfaction to find all the ulcers healed and my patient restored to the bloom of health.

The only local application to the ulcers was ablution with castile soap, and the use of simple cerate.

The remedy adopted in the above case was rather unusual, but having several times combined tobacco with spigelia for the expulsion of worms from children, without any unpleasant effects, the occasion seemed favorable to try its efficacy in temia.

From its success in this case, I have used it very frequently since, especially in adults, where the presence of worms ofttimes induces serious disturbances of the system, without being suspected, as will appear from the following case.

Mr. B, aged 30, applied to me in 1816 , for relief of a complaint under which he had been laboring for six months-several physicians to whom he had applied, having failed in affording any relief.

He complained of an uneasiness about the umbilicus-it did not amount to pain, nor was it sore on pressure, but the sensation was of a nature to distress him very much. His appetite was greater than natural, and he indulged it; but he was daily wasting away. His food did not strengthen him, and still digestion was fully performed-lus bowels were regular, tongue clean, complexion sallow.

On giving my opinion that worms were the cause of his complaint, he eagerly embraced the idea and agreed to submit to my treatinent. He was treated precisely as the case above related. After taking the eighth portion, nausea to a distressing degree was excited, and he described his feelings to be "as if a pound of lead had separated from his navel and fell to the bottom of his belly, where it lay as a lump of lead or clay."

A brisk cathartic was given, and more than one hundred lumbrici were expelled, all dead, and the ascarides were, as he said, innumerable.

Health, vigor of body and serenity of mind, were the immediate followers of this verminose treatment.-Transylvania Med. Jour.

BOSTON MEDICAL AND SURGICAL JOURNAL.

BOSTON, DECEMBER 14,1836 .

\section{S'TATE PRISON HOSPITAL.}

Having been politely invited by one of the Commissioners of the State Prison, at Charlestown, to visit that institution the other day, we were 